\title{
Correlation of marine and terrestrial Upper Cretaceous sediments by their magnetic susceptibility
}

\author{
H. J. HANSEN, K. L. RASMUSSEN, LIU QINGSHENG, C. BENJAMINI, I. WALASZCZYK, \\ R. GWOZDZ and M. STAGE
}

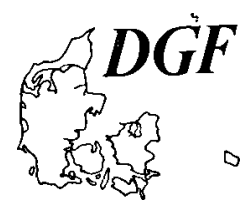

\begin{abstract}
Hansen, H. J., Rasmussen, K. L., Liu Quingsheng, Benjamini, C. Wa laszczyk, I., Gwozdz, R. and Stage, M.: Correlation of marine and terrestrial Upper Cretaceous sediments by their magnetic susceptibility. Bull. geol. Soc. Denmark, Vol. 40, pp. 175-184. Copenhagen, June 3th, 1993. https://doi.org/10.37570/bgsd-1993-40-08
\end{abstract}

\begin{abstract}
Plots of magnetic susceptibility versus depth of sediment samples from both marine and terrestrial series demonstrate that, within a specified time interval constrained by magneto- and biostratigraphy, it is possible to interpret the pattern in terms of orbitally driven sedimentary cycles (Gilbert - or Milankovic cycles) with periodicities of around 100 and $20 \mathrm{Ka}$ respectively. At present the method allows correlation of marine and terrestrial deposits with a time resolution of about $10 \mathrm{Ka}$.

Some peaks have characteristic shapes and interference patterns that may be recognized over wide areas. Sediment series have been studied from central Poland, south Israel, south France, south China and Denmark. December 20th, 1992.
\end{abstract}

H. J. Hansen \& R. Gwozdz, Geologisk Institut, Oster Voldgade 10, DK-1350 Kobenhavn K, Denmark. K. L. Rasmussen \& M. Stage, Fysisk Institut, Odense Universitet, Campusvej, DK-5230 Odense M, Denmark. Liu Quingsheng, Department of applied Geophysics, China University of Geosciences, Wuhan, Hubei 430074, P.R. China. C. Benjamini, Department of Geology and Mineralogy, Ben Gurion University of Negev, P. O.B. 653, Beer Sheva 84 105, Israel. I. Walaszczyk, Institute of Geology, University of Warsaw, Al. Zwirki i Wigury 93, 02 089, Warszawa, Poland.

\section{Introduction}

The present study is concerned with the fluctuations in magnetic susceptibility of sediments of the latest Cretaceous time interval constrained by magnetostratigraphy as well as the biostratigraphical Cretaceous-Tertiary boundary which, in the marine realm, is rather easy to establish. The boundary between the normal magnetic interval 30 and the reversed interval 29 lies below the K-T boundary. The duration of the reversed part of chrone 29 has been estimated at $869 \mathrm{Ka}$ (Cande $\&$ Kent, 1992) or $600 \mathrm{Ka}$ (Berggren et al. 1985). The K-T boundary has been found to lie in the reversed interval 29 with about $2 / 3$ earlier than the boundary and $1 / 3$ occurring later than the boundary (Alvarez et al., 1977).

We selected for our study sections where the magnetostratigraphy was already established. However, in the Danish region no reliable magnetostratigraphy has so far been established for the uppermost Cretaceous.

Two short accounts of some results of the appli- cation of the method described below was published by Hansen et al. (1992 a,b).

\section{Methods}

Samples have been measured for their magnetic susceptibility in a Kappa KLY-2 instrument. Different measuring procedures were used depending upon the sample type. Drilled plugs have been measured in a cylindrical perspex container while loose sediments were kept in medical pill containers with a diameter of $4 \mathrm{~cm}$ and filled to a level $4 \mathrm{~cm}$ above the bottom of the container. The active measuring volumen of our KLY-2 instrument is a cylinder with diameter and height of $4 \mathrm{~cm}$. Various containers have been tried for their susceptibility properties. We found that the medical pill containers were the most constant and rather low in diamagnetism relative to other commercially available sample containers.

The measuring sequence is particularly impor- 
tant for measurements in the diamagnetic range. The sequence applied in this investigation is: 4 times empty container, 4 times one sample from the sequence followed by 10 different samples from the sequence (in random order), 4 times empty etc.

This allows correction and repeated measuring of samples if instrumental drift should occur during the measuring process. The zero value for the empty container has been subtracted from the measurements.

The sampling equidistance varies from one locality to another. The spacing in some marine chalks is $1 \mathrm{~cm}$ whereas in other sediments $10 \mathrm{~cm}$ have turned out to yield sufficient resolution. Whatever sampling interval has been used, we always sampled a short interval in great detail in order to see if a substructure could be recognized.

\section{Sections sampled}

Nasilow, middle Vistula Valley, central Poland

The Nasilow section is in the bank of the Vistula River facing the town of Kazimierz on Vistula. The section is well exposed in an abandoned quarry.

The magnetostratigraphy of the section at Nasilow has been published recently (Hansen et al. 1990). The boundary between $29 \mathrm{R}$ and $30 \mathrm{~N}$ lies between 6.3 and $8.6 \mathrm{~m}$ below the biostratigraphic K-T boundary.

The chalk is weakly bedded with a bedding thickness in the range of 1.5 to $2.5 \mathrm{~m}$. The chalk, termed "opoka", is rather heavily impregnated with silica and has a lower carbonate content than the white chalk of Denmark. The locality and its macrofauna has been described by Radwanski (1965), Abdel-Gawad (1986) and Machalski \& Walaszczyk $(1987,1988)$.

The section was sampled by drilling $2.5 \mathrm{~cm}$ plugs at a spacing of $2.5 \mathrm{~cm}$. This resulted in about 20 plugs per meter.

\section{Hor Zin, Israel}

In the early literature, the locality Hor Zin is termed Hor Hahar (Anomynous). It is situated ca. $60 \mathrm{~km}$ south of the town Beer Sheva in the Negev region. The section exposes rhythmic ma- rine sediments showing changes from darker shaly to more whitish carbonate-rich intervals. Part of the section has been described by Margaritz et al. (1985), Keller et al. (1990), Keller \& Benjamini (1991) and Eshet et al. (1992).

The section sampled in this study lies $1.5 \mathrm{~km}$ further east relative to that described earlier. The published section did not expose more than $4 \mathrm{~m}$ of Upper Cretaceous sediments. The more easterly outcrop exposes additionally $11 \mathrm{~m}$. The magnetostratigraphy of the first section was published by Margaritz et al. (op. cit.) and that section terminated in the $29 \mathrm{R}$ interval without reaching the $30 \mathrm{~N}$ interval.

In the more easterly section a preliminary collection of samples for magnetostratigraphy was made. We did, however, only succeed in finding specimens with normal magnetization. By combining the two sections we may preliminarily place the $29 \mathrm{R}-30 \mathrm{~N}$ boundary within the depth interval from 1095 to $1140 \mathrm{~cm}$ in our susceptibility plot.

Samples for susceptibility measuremènts were collected as pieces from excavated trenches. The sample equidistance was around $5 \mathrm{~cm}$. Specimens for paleomagnetic measurements'were oriented samples, which were later prepared in the laboratory.

\section{Aix-en-Provence, south France}

The continental Upper Cretaceous redbeds crop out east of the town Aix-en-Provence. The preliminary magnetostratigraphy has been described by Hansen et al. (1989). These authors suggested a position of the $29 \mathrm{R}-30 \mathrm{~N}$ to be about $26 \mathrm{~m}$ below the conglomerate Poudingue-de-Galante.

The section studied is the locality "Carriere" a little outside the village Puyloubier. The locality exposes $41.5 \mathrm{~m}$ sediments. An interval of $2.2 \mathrm{~m}$ situated around the $14 \mathrm{~m}$ level in the profile is characterized by a dark purple colouration which we found was due to a content of elementary carbon as well as sub- millimetre pieces of charcoal as seen in palynofacies preparations. The section was sampled with an equidistance of 10 $\mathrm{cm}$. 

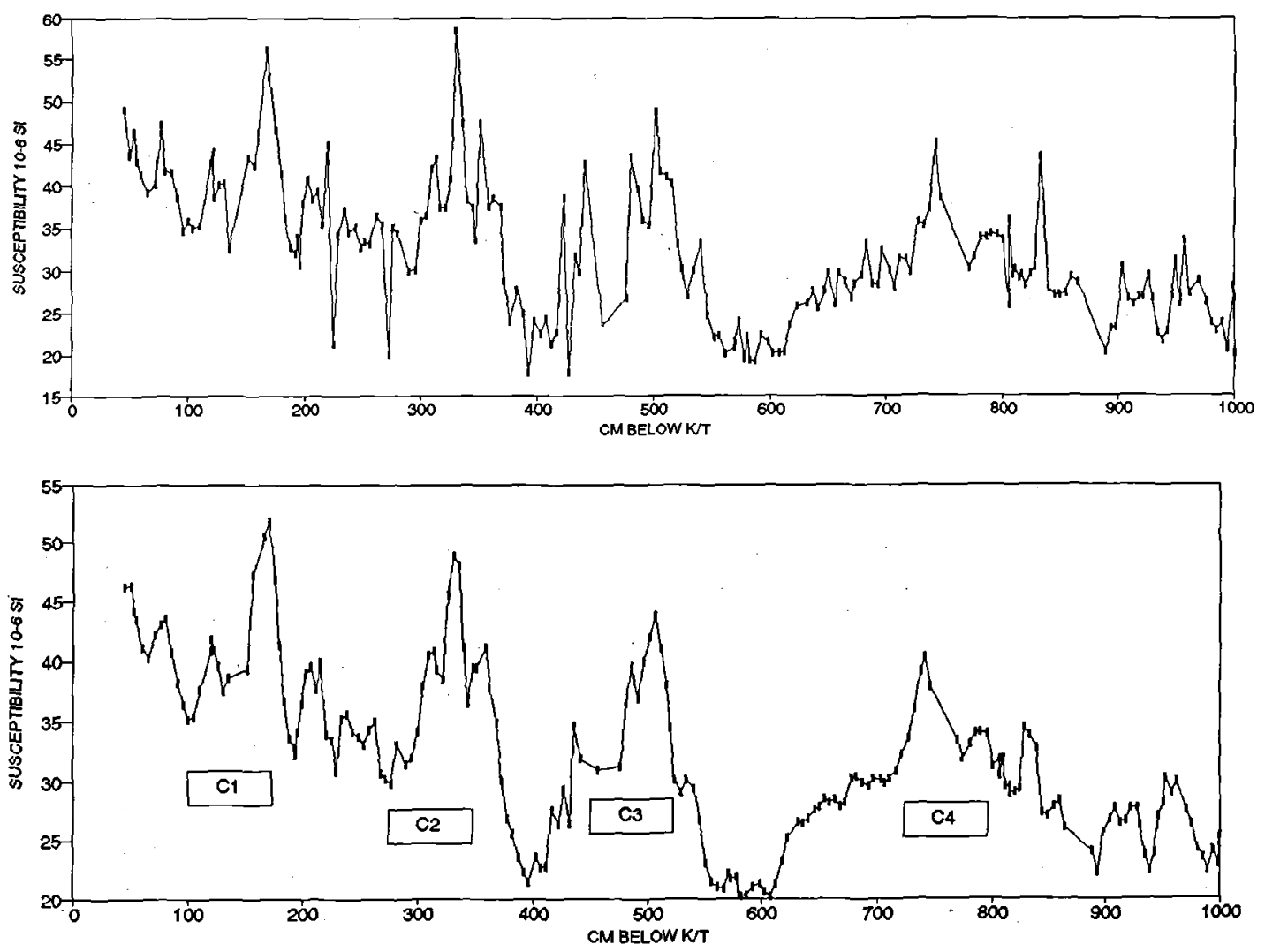

Fig. 1. Magnetic susceptibility versus stratigraphic depth from Nasilow, central Poland. Upper figure is the unfiltered data while the lower figure is filtered 3-point square. In this and the following figures the K/T boundary is found at the zero level on the $\mathrm{x}$-axis. The interval shown in the figures roughly corresponds to the Cretaceous part of magnetochrone $29 \mathrm{R}$.

\section{Datong, Nanxiong Basin, south China}

The locality Datong is situated $25 \mathrm{~km} \mathrm{NE}$ of the town of Nanxiong, which again is found $250 \mathrm{~km}$ NNE of Guangzhou (formerly Canton). The Upper Cretaceous sediments exposed at Datong in the Nanxiong Basin exposes continental redbeds with a very clear rhythmic development. At regular intervals hardened beds occur throughout the section.

The magnetostratigraphy indicates that the change from $29 \mathrm{R}$ to $30 \mathrm{~N}$ is found between 38 and $42 \mathrm{~m}$ below the boundary between the Nanxiong Formation and the overlying Shanghu Formation (Liu et al. 1992).

The sampling equidistance was $23 \mathrm{~cm}$ in the interval from the formational boundary downwards to a depth of $44 \mathrm{~m}$ in the uppermost part of the Nanxiong Formation. The lowermost $6 \mathrm{~m}$ of the overlying Shanghu Formation were sampled with an equidistance of $13 \mathrm{~cm}$, while the overlying $3 \mathrm{~m}$ were sampled in steps of $10 \mathrm{~cm}$.

\section{Rødvig, Stevns Klint, Denmark}

The uppermost Maastrichtian white chalk with a grey colouration caused by elementary carbon (Hansen et al. 1987) crops out in the southernmost part of the Stevns Klint exposure. It is distinctly bedded and consists of 6 beds. The white chalk - grey chalk incipient hardground is found in the 7th bed below the Fish Clay which marks the Cretaceous-Tertiary boundary.

The uppermost 4 beds were collected in blocks that were cut in the laboratory into $8 \mathrm{~mm}$ slices using a rock saw. The saw-cut obliterated $2 \mathrm{~mm}$ of rock. The single slab was washed and burrows of Thalassinoides type were marked with pencil and carefully avoided when the dried slabs later were crushed and filled into pill containers. Our experience shows that Thalassinoides burrows 


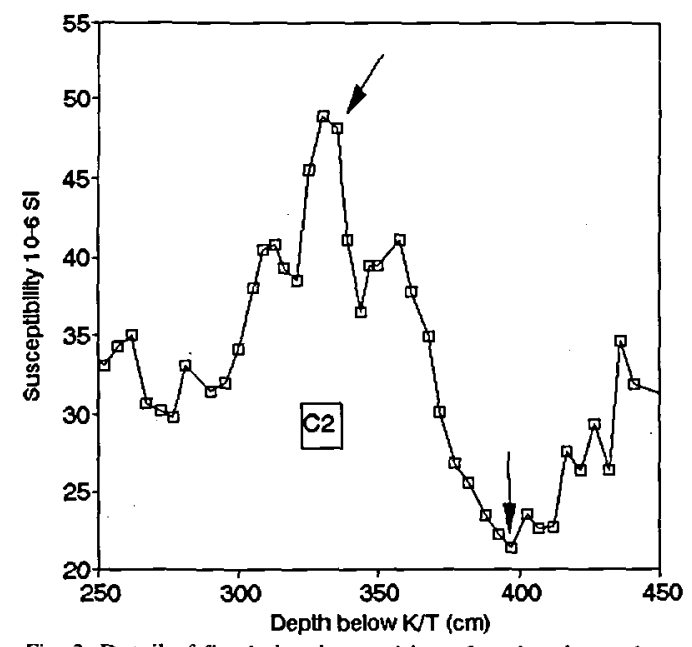

Fig. 2. Detail of fig. 1 showing position of analysed samples.

are particularly descructive of the signal resolution by contrast to most other burrow types.

We have made 3 attempts to establish a magnetostratigraphy for the Stevns Klint section. All 3 have failed because of extremely low signal.

\section{Nye Kløv, Denmark}

The section at Nye Kløv in northern Jylland exposes the Cretaceous-Tertiary boundary marked by a lateral equivalent of the Fish Clay from Stevns Klint. It is, however, a tectonic breccia containing sharp clasts of white chalk and the overlying "dead layer".

The white chalk beneath this is bedded with a thickness of the individual beds around $20 \mathrm{~cm}$. From the Cretaceous-Tertiary boundary downsection a series of coherent blocks were sampled. In the laboratory these were cut into $8 \mathrm{~mm}$ slices using a rock saw. Again $2 \mathrm{~mm}$ was lost by the saw-cut. The slices were washed and burrows of the Thalassinoides type were marked with pencil.

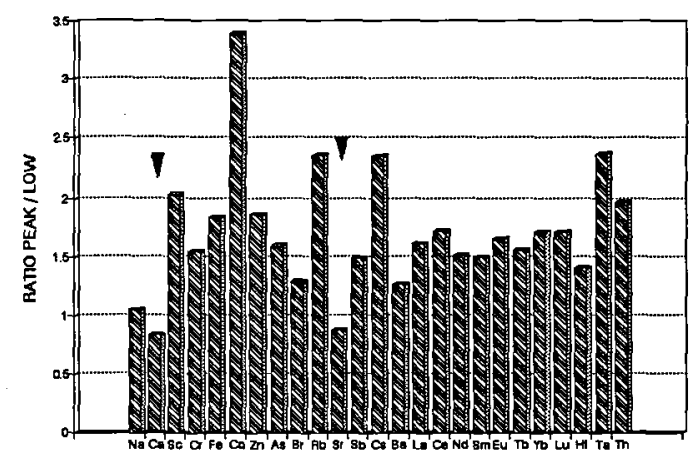

Fig. 3. Ratio between the two samples indicated in fig. 2 . The arrows in the figure point to the two depleted elements $\mathrm{Ca}$ and Sr.

After drying the slices were crushed and filled into medical pill containers and the marked areas were omitted.

We have made one attempt to establish a magnetostratigraphy for this section, but as at Stevns the attempt was unsuccessful for the same reason.

\section{Observations}

Poland

The magnetic susceptibility values plotted against stratigraphical height for the Cretaceous part of magnetochron 29R are shown in fig. 1.

It appears that two pronounced periodicities are present. The larger peaks correspond to roughly $100 \mathrm{Ka}$ while the smaller ones correspond to ca. $20 \mathrm{Ka}$. We suggest that the pulses correspond to the ellipse-precessional complex in the Milankovitch band (see e.g. Fisher and Bottjer, 1991), or alternatively the obliquity cycles complex as suggested by Liu (1992).

We made instrumental neutron activation anlysis of samples from pulse C2 (fig. 2). A compari-

Table 1. Results of instrumental neutron activation analysis of samples from Nasilow, Central Poland in the interval C2 (compare fig. 3).

\begin{tabular}{|c|c|c|c|c|c|c|c|c|c|c|c|c|c|c|c|c|c|c|c|c|c|c|c|c|c|}
\hline $\begin{array}{l}\text { Sarn } \\
\text { ple }\end{array}$ & $\mathrm{Na}$ & $\mathrm{Ca}$ & Sc & $\mathrm{Cr}$ & $\mathrm{Fe}$ & Co & $\mathrm{Zn}$ & As & $\mathrm{Br}$ & $\mathbf{R b}$ & $\mathrm{Sr}$ & $\mathrm{Sb}$ & Cs & $\mathbf{B a}$ & $\mathbf{L a}$ & $\mathrm{Ce}$ & Nd & Sm & Eu & $\mathrm{Tb}$ & $\mathrm{Yb}$ & Lu & Hf & $\mathrm{Ta}$ & Th \\
\hline 335 & 565 & 253000 & 2.25 & 40,6 & 11000 & 1.74 & 23.6 & 3.61 & 1.28 & 33 & 772 & 0,178 & 1,65 & 91,4 & 6,79 & 14,1 & 6,79 & 1,12 & 0,249 & 0,176 & 0,654 & 0,0876 & 1,48 & 0.266 & 2,34 \\
\hline 339 & 500 & 2630000 & 1,62 & 35,6 & 8610 & 0,915 & 23,4 & 3,27 & 1,02 & 24,2 & 783 & 0,186 & 1,17 & 68,9 & 5,23 & 10,6 & 5,47 & 0,95 & 0,192 & 0,176 & 0,394 & 0.0678 & 1.13 & 0,181 & 1,66 \\
\hline 343 & 490 & 2861000 & 1.61 & 32,2 & 8030 & 0,944 & 13,6 & 2,5 & 1,18 & 21.7 & 848 & 0,154 & 1,11 & 78,7 & 5,44 & 10,9 & 6,44 & 0,98 & 0,204 & 0,135 & 0,506 & 0,0632 & 1,09 & 0.157 & 1.72 \\
\hline 347 & 464 & 2700000 & 1.5 & 29,8 & 7360 & 0.73 & 7,63 & 2,6 & 1,01 & 19,9 & 789 & 0,166 & 1,02 & 64,3 & 5,03 & 10,5 & 4,95 & 0,926 & 0,186 & 0.128 & 0,472 & 0.067 & 1.21 & 0.154 & 1.63 \\
\hline 382 & 916 & 289000 & 1.04 & 28,2 & 5220 & 0,966 & 11,7 & 2,07 & 0,942 & 14.4 & 823 & 0.173 & 0.671 & 67 & 3,85 & 8,12 & 4,45 & 0.695 & 0.15 & 0.111 & 0.479 & 0.0611 & 0.894 & 0.116 & 1.21 \\
\hline 388 & 398 & 3030000 & 1.15 & 26.3 & 5720 & 0.987 & 10.8 & 2,13 & 1,06 & 15.4 & 884 & 0.103 & 0.69 & 58,4 & 4,1 & 7,82 & 4,31 & 0.737 & 0,148 & 0,101 & 0.374 & 0.0528 & 0,821 & 0,12 & 1.2 \\
\hline 393 & 535 & $30 t 000$ & 1.1 & 26 & 5940 & 0.512 & 12.6 & 2.25 & 0.977 & 14 & 873 & 0,118 & 0,701 & 71,5 & 4,16 & 8,12 & 4,43 & 0.741 & 0,149 & 0.112 & 0.38 & 0,0509 & 1,04 & 0,112 & 1.18 \\
\hline 397 & 481 & 281000 & 1.11 & 24.7 & 5540 & 0.685 & 13,1 & 2,07 & 1.02 & 15,5 & 805 & 0,116 & 0,725 & 62,9 & 4,04 & 7,86 & 4,47 & 0.71 & 0,146 & 0,118 & 0,33 & 0,0483 & 0.794 & 0,111 & 1.2 \\
\hline
\end{tabular}



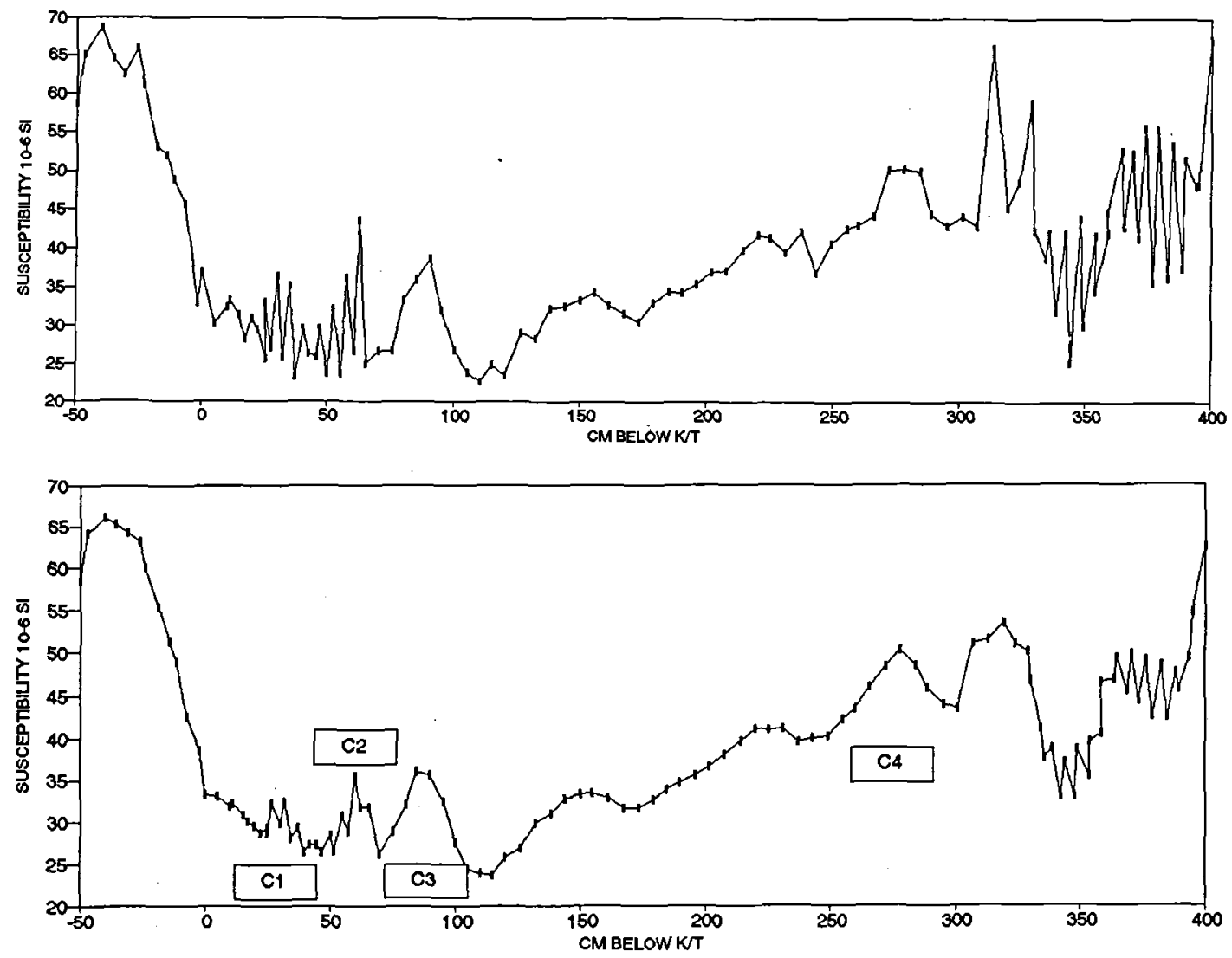

Fig. 4. Magnetic susceptibility versus stratigraphic depth from Hor Zin, Israel. Upper figure is the unfiltered data while the lower figure is filtered 3-point square.

son between two samples illustrates the difference between trace elements from a peak and the corresponding trough. Table 1 lists the values obtained by instrumental neutron activation analysis. The ratio in trace elements between the highest and lowest susceptibility signals is shown in fig. 3. All elements analysed with the exception of $\mathrm{Ca}$ and $\mathrm{Sr}$ show enrichment in the sample with peak susceptibility. We interpret the difference in trace elements as caused by variations in precipitation, leading to greater or lesser influx of terrigenous material in the chalk.

The susceptibility curve (fig. 1) exhibits some characteristic features. To ease the interpretation we have tentatively numbered what we believe to be the $100 \mathrm{Ka}$ cycles. Peak C2 interferes with the short periodicity signal resulting in a major peak with two shoulders. Peak C4 is followed by a "long" slope with two minor pulses.
Israel

The corresponding interval from Israel (fig. 4) shows the same characteristic development of pulse order and shape as in Poland. It does, however, also demonstrate a pronouced change in sedimentation rate from $\mathrm{C} 4$ to $\mathrm{C} 1$.

Below $\mathrm{C} 4$ is a remarkable period showing strongly fluctuating signal superimposed upon a precessional signal.

\section{France}

To our astonishment we found patterns in the terrestrial redbeds in France similar to those of the marine sections in Poland and Israel (fig. 5). $\mathrm{C} 2$ with two shoulders may be recognized as well as the characteristic "long slope" following C4. What is further remarkable is the presence, at the interval of absolute minimum susceptibility around $14 \mathrm{~m}$, of an interval coloured by ele- 

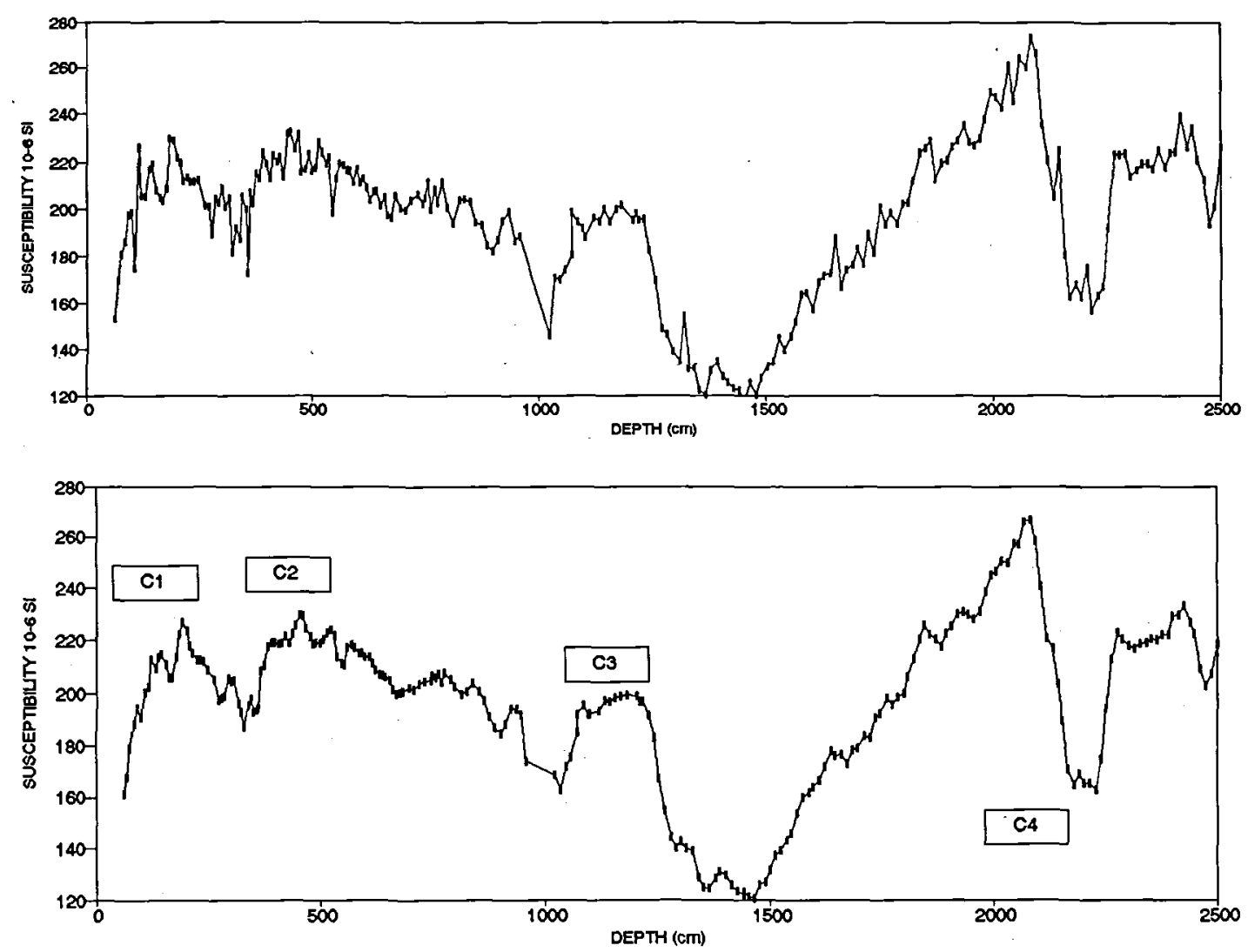

Fig. 5. Magnetic susceptibility versus stratigraphic depth from Aix-en-Provence, south France. Upper figure is the unfiltered data while the lower figure is filtered 3-point square.

mental carbon and charcoal. It indicates a period of pronounced forest fires. This supports our suggestion that the variation in signal may be related to precipitation.

\section{China}

The Chinese series is less clear in its pattern (fig. 6). The major pulses which we interpret in terms of maximum precipitation are marked by hardened beds that occur at regular intervals. One of them we interpret as a mudflow and a few contain a sandstone bed with Ophiomorpha. Samples drilled from the hardened beds for magnetostratigraphy (Liu et al. 1992) were measured for their magnetic susceptibility. The values correspond to the surrounding sediments. However, thin sections of the hardened beds showed a quartz content of at least $50 \%$. If the sample weight is corrected for the high quartz content, the hardened beds would indeed represent rather high susceptibility peaks.
The suggested $\mathrm{C} 4$ is followed by an interval with strongly fluctuating signal.

An interval (fig. 6 from $\div 3$ to $\div 2 \mathrm{~m}$ ) was sampled so that each sample covered $10 \mathrm{~cm}$ profile thickness. Homogenized aliquots were measured for their magnetic susceptibility and were subjected to instrumental neutron activation analysis. The resulting values are recorded in fig. 7 and table 2. It appears that the susceptibility signal is strongly correlated with iron and siderophile elements.

The two samples with highest and lowest susceptibility signal respectively were analyzed by Mössbauer spectroscopy at the Niels Bohr Institute in an attempt to find magnetite. No trace of magnetite was found.

\section{Stevns Klint}

It was suggested by Hansen et al. (1986) that the uppermost Maastrichtian sequence at Stevns Klint is incomplete. The suggestion was based on 

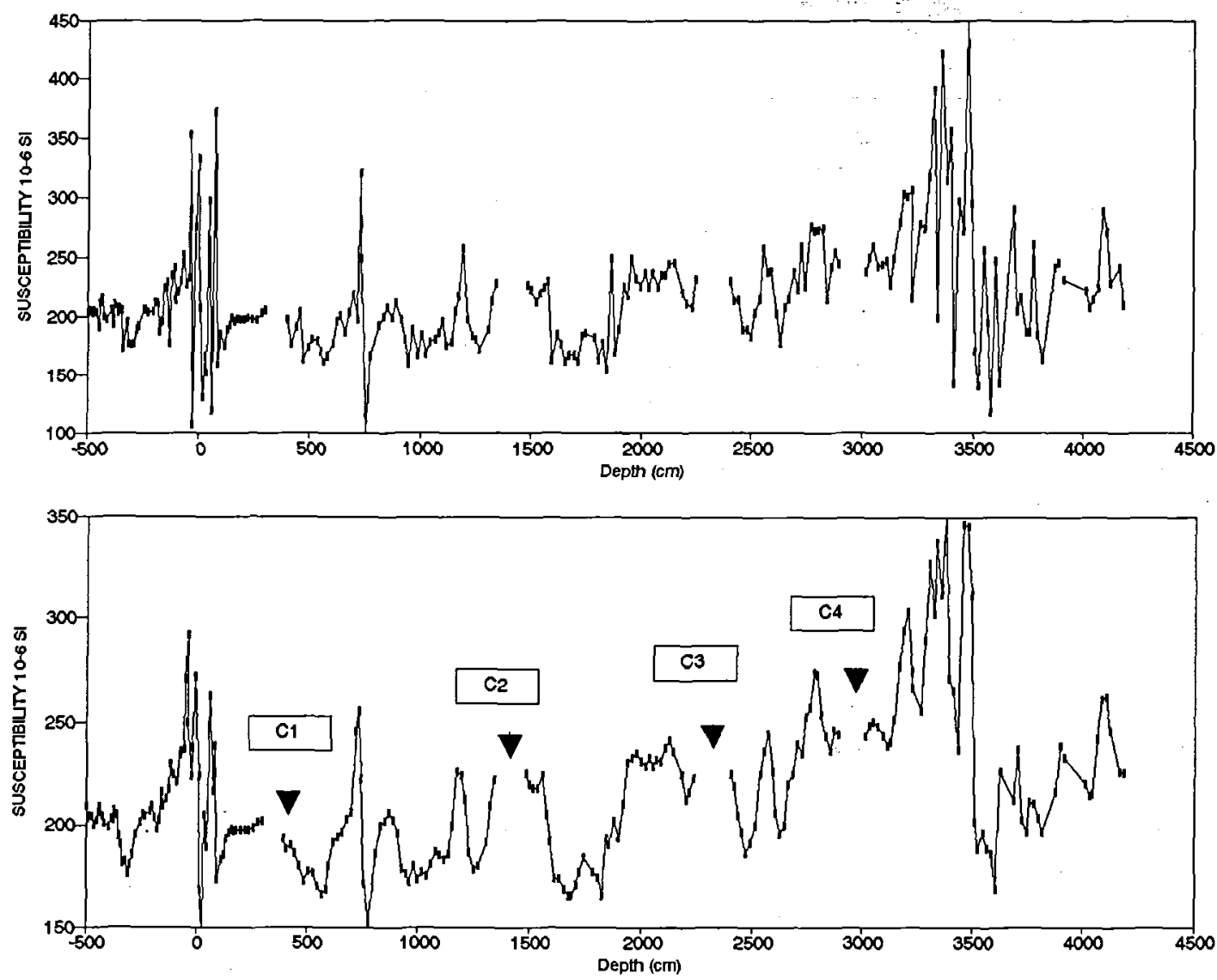

Fig. 6. Magnetic susceptibility versus stratigraphic depth from Nanxiong, China. Upper figure is unfiltered data while the lower figure is filtered 3-point square.

the find in northern Jylland of a negative carbon isotope anomaly in the material of dinoflagellate cysts occurring $15 \mathrm{~cm}$ below the $\mathrm{K} / \mathrm{T}$ boundary. The corresponding anomaly also found in dinoflagellate cysts at Stevns Klint occurs at the base
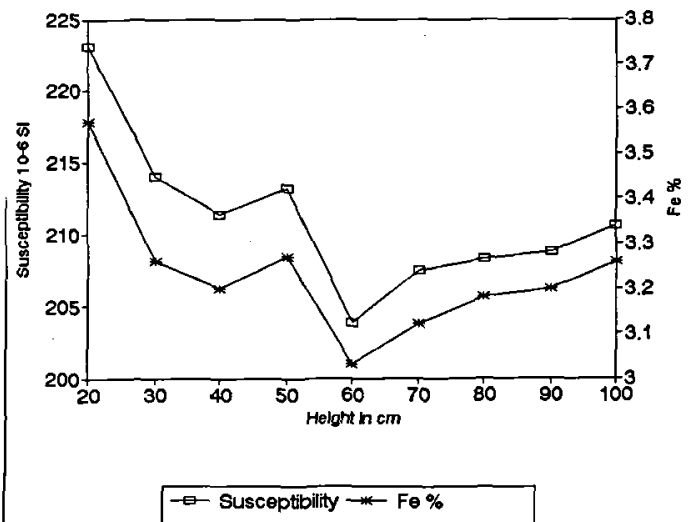

Fig. 7. Magnetic susceptibility versus iron content in 9 consequetive samples from Nanxiong, China. of the Fish Clay. Thus at Stevns Klint sediments are lacking that correspond to $15 \mathrm{~cm}$ white chalk at Nye Kløv. In spite of an unsatisfactory stratigraphic resolution from the latter locality, the interval missing at Stevns Klint can be estimated to around $100 \mathrm{Ka}$ (or one bed).

The susceptibility series from Stevns Klint is shown in fig. 8 . We suggest that the series be interpreted with the uppermost $100 \mathrm{Ka}$ missing. The general trend in the uppermost 3 beds is one of general decrease in signal level, as in Poland. The C4 - C5 interval is very noisy, like the corresponding intervals in Israel and China.

\section{Nye Kløv}

From the measured sequence at Nye Kløv (fig. 9) it appears quite evident that the bedding observed in the field corresponds well with the maxima in the susceptibility plot. It is, however, also 
Table 2. Results of instrumental meutron activation analysis of 9 samples from Nanxiong, China (compare fig. 7).

\begin{tabular}{|c|c|c|c|c|c|c|c|c|c|c|c|c|c|c|c|c|c|c|c|c|c|c|c|c|c|c|}
\hline $\begin{array}{l}\text { Sam- } \\
\text { ple }\end{array}$ & Height & $\mathrm{Na}$ & $\mathrm{Ca}$ & Sc & $\mathrm{Cr}$ & $\mathrm{Fe}$ & $\mathrm{Co}$ & $\mathrm{Zn}$ & As & Se & $\mathbf{R b}$ & $\mathrm{Sr}$ & Sb & Cs & $\mathrm{Ba}$ & $\mathrm{La}$ & $\mathrm{Ce}$ & $\mathrm{Nd}$ & Sm & Eu & $\mathrm{Tb}$ & $\mathbf{Y b}$ & Lu & Hf & Ta & Th \\
\hline S3-9 & 20 & 5,38 & 2,05 & 1,23 & 7,09 & 3,57 & 1,34 & 7,05 & 2,08 & 2,92 & 2,14 & 5,1 & 1,4 & 3,17 & 4,9 & 4 & 7,08 & 3,69 & 6,46 & 1,23 & 1,03 & 3,12 & 4,4 & 5,65 & 1,47 & 1.7 \\
\hline S3-8 & 30 & 5,35 & 2,97 & 1.16 & 6,75 & 3,26 & 1,27 & 6,53 & 1,85 & 1,04 & 1,96 & 1,13 & 1,47 & 3,05 & 5,35 & 3,75 & 6,93 & 3,84 & 6.23 & 1,18 & 1,09 & 3,17 & 4,31 & 6,03 & 1.51 & 1.6 \\
\hline S3-7 & 40 & 6,05 & 2,23 & 1,13 & 6,54 & 3,2 & 1,18 & 6,27 & 1,78 & 1,46 & 2,01 & 1,04 & 1,33 & 2,98 & 5,47 & 3,82 & 7,13 & 3,14 & 6,16 & 1,19 & 1,07 & 3.24 & 4,22 & 6.21 & 1.52 & 1,6 \\
\hline S3-6 & 50 & 5,33 & 2,16 & 1,14 & 6,47 & 3,27 & 1,21 & 7,16 & 1,81 & 2,35 & 2 & 1,27 & 1,16 & 3,08 & 5,5 & 3,93 & 7,13 & 3,85 & 6,3 & 1,18 & 1,03 & 3.01 & 4,34 & 6,12 & 1.5 & $1,6 t$ \\
\hline S3-5 & 60 & 6,06 & 2,04 & 1,12 & 6,24 & 3,03 & 1,16 & 2,92 & 1,75 & 3,75 & 1,92 & 1,08 & 1,53 & 3,01 & 5,59 & 3,7 & 6,7 & 3,18 & 6,01 & 1,13 & 1,03 & 3,19 & 5,42 & 6,33 & 1,52 & 1,55 \\
\hline S3-4 & 70 & 6,29 & 2,29 & 1.11 & 6,36 & 3,12 & 1,1 & 6,65 & 1,61 & 1,95 & 0,93 & 1,06 & 3,12 & 5,85 & 3,7 & 6,97 & 3,23 & 6,2 & 1,19 & 1,04 & 2,94 & 5,23 & 6,41 & 1,58 & 1.63 & \\
\hline S3-3 & 80 & 5.67 & 2.2 & 1,12 & 6,54 & 3,18 & 1.14 & 6,28 & 1,81 & 1,16 & 2,08 & 9,02 & 1,19 & 3,21 & 5,17 & 3,88 & 7,26 & 3,73 & 6,5 & 1,22 & 1.07 & 3,06 & 5,28 & 6.44 & 1.53 & $1,6 t$ \\
\hline$S 3-2$ & 90 & 5.44 & 2,7 & 1,13 & 6,45 & 3,2 & 1,13 & 5,94 & 1,73 & 2,04 & 6,33 & 1,25 & 3,16 & 5,65 & 3,96 & 7,33 & 4,1 & 6,53 & 1,23 & 1.14 & 3,02 & 4,41 & 6,68 & 1.55 & 1.68 & \\
\hline S3-1 & 100 & 5.5 & 2,07 & 1,15 & 6,85 & 3,26 & 1,15 & 6,5 & 1,84 & 0 & 2,09 & 9,37 & 1,18 & 3,24 & 5,16 & 3,7 & 7,32 & 3,95 & 6.08 & 1,22 & 1,11 & 2,95 & 5,13 & 6.24 & 1.64 & 1.65 \\
\hline
\end{tabular}

rather evident that the stratigraphical resolution is much too low to allow detailed interpretation. We only wish to point out that the $15 \mathrm{~cm}$ top interval roughly corresponds to $100 \mathrm{Ka}$.

We are well aware of the fact that our stratigraphical resolution is smaller than desired for the Nye Kløv section. A new sectioning technique is being developed which will allow a $5 \mathrm{~mm}$ resolution. In spite of the insufficient resolution we are still able to record some presumed precessional cycles in addition to the supposed ellipse signal.

\section{Discussion and conclusions}

From the above observations it is possible to make correlation between marine and terrestrial
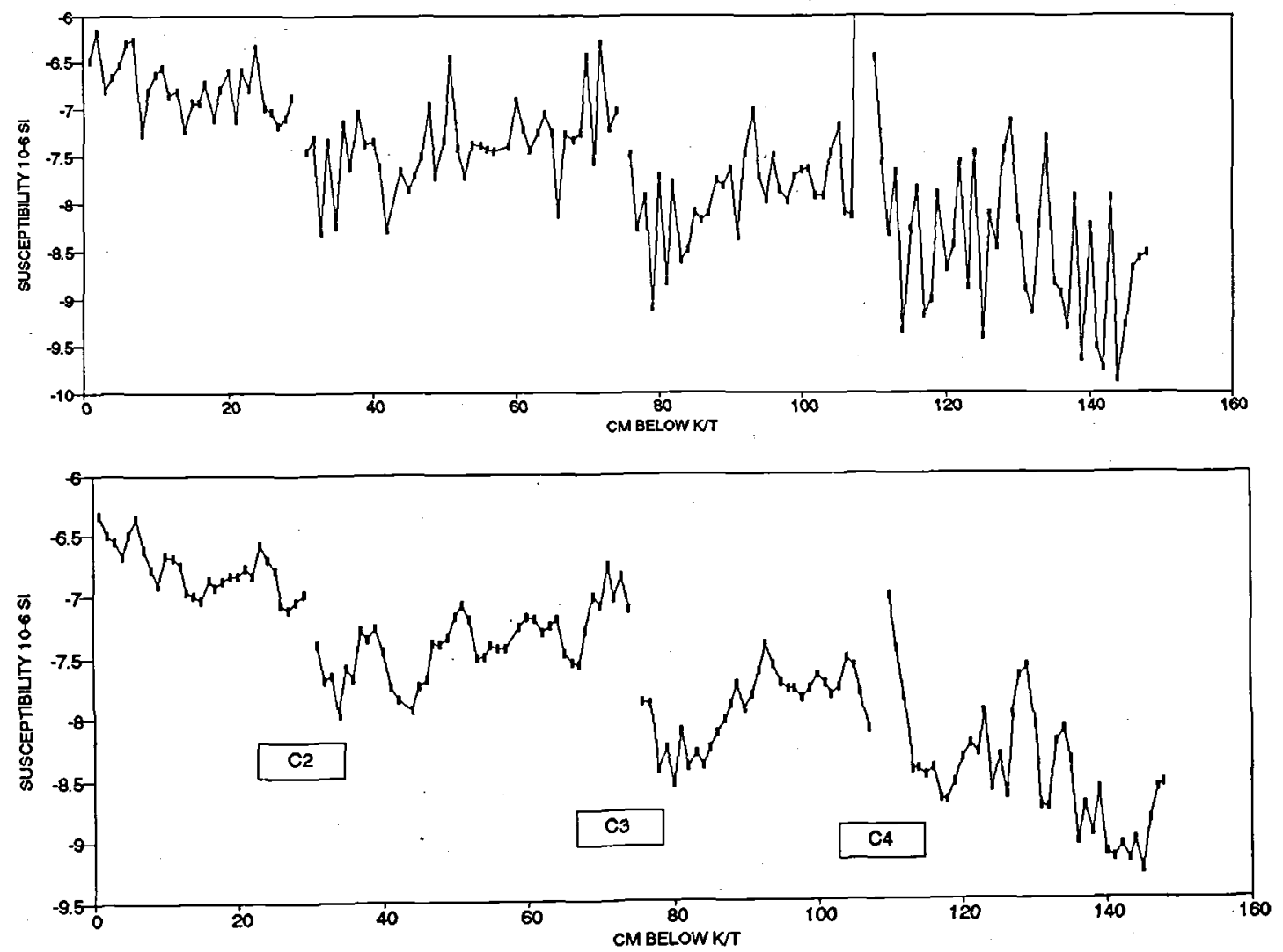

Fig. 8. Magnetic susceptibility versus stratigraphic depth from Rødvig, Stevns Klint, Denmark. Upper figure is the unfiltered data while the lower figure is filtered 3-point square. Note that the susceptibility is in the diamagnetic range. 

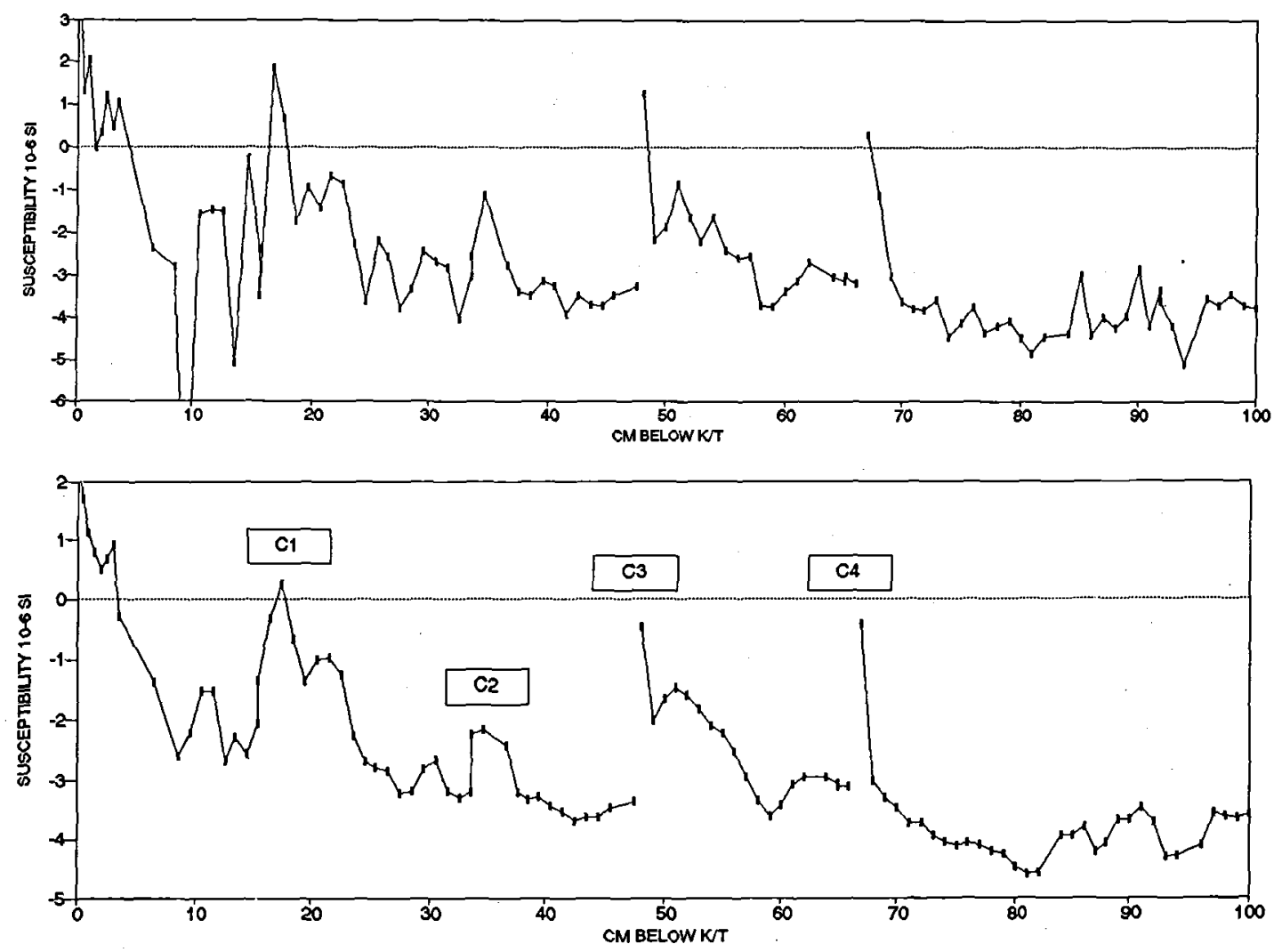

Fig. 9. Magnetic susceptibility versus stratigraphic depth from Nye Kløv, north Jylland, Denmark. Upper figure is unfiltered data while the lower figure is filtered 3-point square.

deposits by their magnetic susceptibility with a resolution around half a precessional cycle or around 10,000 years. It is thereby superior as compared to most other correlation methods.

Hansen et al. (1987) used the position of the Kjølby Gaard Marl to compare accumulation rates across the Danish Basin in Upper Cretaceous time. The position of the Kjølby Gaard Marl in the Stevns region is around $10 \mathrm{~m}$ below the Fish Clay while the corresponding level at Nye $\mathrm{Kl} \emptyset \mathrm{v}$ is around $7 \mathrm{~m}$ below the K-T boundary. This agrees well with the difference in bed thickness between the two Iocalities.

The observed cyclicity can be explained in terms of variations in precipitation. In the marine realm this would result in changes in runoff from land and thereby variations in terrestrial input registered both in productivity changes and systematic variations in trace element content. In the terrestrial realm under arid to semiarid conditions, a systematic variation is found in the con- tent of iron covarying with the susceptibility signal.

It has recently been shown by Knox (1993) and Taylor et al. (1993) that the climatic system can indeed respond to the minute forcing of the precessional and elliptical variations. Our findings support this suggestion.

Acknowledgements. The present study was supported by a grant from the Danish Natural Science Research Council and the Carlsberg Foundation.

Drs. Lise Vistisen, The Niels Bohr Institute and J. M. Knudsen, Institute of Physics kindly undertook the Mössbauer spectroscopy.

\section{Dansk sammendrag}

Ved at måle den magnetiske susceptibilitet af tætte prøveserier af sedimenter fra både land- og havaflejringer fra den allersidste del af kridttiden $i$ en rakke, geografisk set, vidt adskilte lokaliteter (Sydkina, Sydfrankrig, Israel, Centralpolen og Danmark) er det lykkedes at finde karakteristiske, og hermed genkendelige mønstre. Da det studerede tidsintervals langde kan fastlægges med en vis nøjagtighed på grundlag af paleomagnetisk stratigrafi kan mønstrene fortolkes som korresponderende til jordklodens præcession og det elliptiske omløb om solen. 
Kemiske analyser af sedimenterne antyder kraftigt, at variationen i signalet skyldes forskelle i nedbørsmønstret. Dette $k a n$ igen relateres til variation $i$ indstråling af energi fra solen til jorden og hænger sammen med de øvrige planeters træk $\mathrm{i}$ jorden og dermed deformation af jordens bane om solen.

De store baneafvigelser finder sted med en periodicitet på omkring 100.000 år mens de mindre udslag har en periode på ca. 20.000 år. Den bæenkning man iagttager i skrivekridtet repræsenterer 100.000 års fasen.

\section{References}

Abdel-Gawad, G. I. 1986: Maastrichtian non-cephalopod mollusks (Scaphopoda, Gastropoda and Bivalvia) of the Middle Vistula Valley, Central Poland. Acta Geol. Polon., $36,(1 / 3), 66-224$.

Alvarez, W., Arthur, M. A., Fisher, A. G., Lowrie, W., Napoleone, G. \& Premoli-Silva, I. 1977: Upper CretaceousPaleocene magnetic stratigraphy at Gubbio, Italy, V, Type section for the late Cretaceous-Paleocene geomagnetic reversal time scale. Geol.Soc. Am. Bull., 88, 383-389.

Anonymous: The Holy Bible.

Berggren, W. A., Kent, D. V. and Flynn, J. J. 1985: Paleogene geochronology and chronostratigraphy in The chronology of the geological record (N. J. Snelling ed.). Geol. Soc. Amer., Mem. 10, 141-195:

Cande, S. C. \& Kent, D. V. 1992: A new geomagnetic polarity time scale for the Late Cretaceous and Cenozoic. Journal of geophysical Research, 97, 13917-13951.

Eshet, Y., Moshkovitz. S., Habib, D., Benjamini, C. \& Magaritz, M. 1992: Calcareous nannofossil and dinoflagellate stratigraphy across the Cretaceous/Tertiary boundary at Hor Hahar, Israel. Marine Micropaleontology, 18, 199228.

Fisher, A. G. and Bottjer, D. J. 1991: Orbital forcing and sedimentary sequences. J. Sed. Petr. 61, 1063-1069.

Hansen, H. J., Gwozdz, R., Hansen, J. M., Bromley, R. G. \& Rasmussen, K. L. 1986: The diachronuous C/T plankton extinction in the Danish Basin. Lecture notes in Earth Sciences, 8, 381-384, Springer Verlag.

Hansen, H. J., Rasmussen, K. L., Gwozdz, R. and Kunzendorf, H. 1987: Iridium-bearing carbon black at the Cretaceous-Tertiary boundary. Bull. geol. Soc. Denmark, 36, 305-314.

Hansen, H. J, Rasmussen, K. L. \& Gwozdz, R. 1989: The continental Cretaceous-Teriary boundary in the Aix-en-
Provence region, south France. Cahiers de la Reserve geologique de Haute Provence. 1, 83-90.

Hansen, H. J., Rasmussen, K. L., Gwozdz, R., Hansen, J. M. \& Radwanski, A. 1990: The Cretaceous-Tertiary boundary in central Poland. Acta Geologica Polonica. 39, 1-12. (dated 1989 but published 1990).

Hansen, H. J., Rasmussen, K. L.. Gwozdz, R. \& Walaszczyk, I. 1992: Time structure of a mass extinction: The Cretaceous-Tertiary boundary. Meteoritics 27, 3, 230 only.

Hansen, H. J., Rasmussen, K. L., Gwozdz, R. \& Walaszczyk, I. 1992b: Cyclic sedimentation in the Polish Upper Cretaceous. Abstracts of 4th International Cretaceous Symposium. 2 pp. University of Hamburg.

Keller, G. \&. Benjamini, C. 1991: Paleoenvironment of the eastern Tethys in the Early Paleocene. Palaios, 6, 439-464.

Keller, G., Benjamini, C., Margaritz, M. \& Moshkovitz, S. 1990: Faunal, erosional and $\mathrm{CaCO}_{3}$ events in the early Tertiary, eastern Tethys. Geol. Soc. Amer., Spec. pap. 247, 471-480.

Knox, J. C. 1993: Large increase in flood magnitute in response to modest changes in climate. Nature, 361, 430-432.

Liu, H.-S. 1992: Frequency variations of the Earth's obliquity and the 100-kyr ice-age cycles. Nature, 358, 397-399.

Liu Qingsheng, Hansen, H. J., Rasmussen, K. L. \& Gwozdz, R. 1992: Magnetostratigraphy of the Cretaceous-Tertiary Boundary of Datong Section at Nanxiong Basin, Guangdong Province. Special issue on Geophysical exploration, 1 . 121-125. China University of Geosciences Press, Wuhan.

Machalski, M. \& Walaszczyk, I. 1988: The youngest (uppermost Maastrichtian) ammonites in the Middle Vistula Valley, Central Poland. Bull. Polish Acad. Sci., Earth Sci, 36 (1), 67-70.

Machalski, M. \& Walaszczyk, I. 1987: Faunal condensation and mixing in the uppermost Maastrichtian/Danian greensand (Middle Vistula Valley, Central Poland). Acta Geol. Polon., $37(1 / 2), 75-91$.

Magaritz, M., Moshkovitz, S., Benjamini, Ch., Hansen, H. J., Haakansson, E. \& Rasmussen, K. L. 1985: Carbon isotope-, bio- and magnetostratigraphy across the CretaceousTertiary boundary in the Zin Valley, Negev, Israel. Newsl. Stratigr. 15, 2, 100-113.

Radwanski, A. 1985: Cretaceous, in: Z. Belka, B. A. Matyja \& A. Radwanski (eds) Field-guide of the geological excursion to Poland, 71-78. University of Warsaw.

Taylor, K. C., Lamorey, G. W., Doyle, G. A., Alley, R. B., Grootes, P. M., Mayewski, P. A., White, J. W. C. \& Barlow, L. K. 1993: The "flickering switch" of late Pleistocene climatic change. Nature, 361, 432-436. 